PRZEGLĄD BIBLIOTECZNY 2018 z. 3

PL ISSN 0033-202X

\author{
ARTUR ZNAJOMSKI \\ Instytut Informacji Naukowej i Bibliotekoznawstwa \\ UMCS w Lublinie \\ e-mail: aznajomski@o2.pl
}

\title{
BIBLIOGRAFIE LOKALNE W OPINII KRYTYKÓW
}

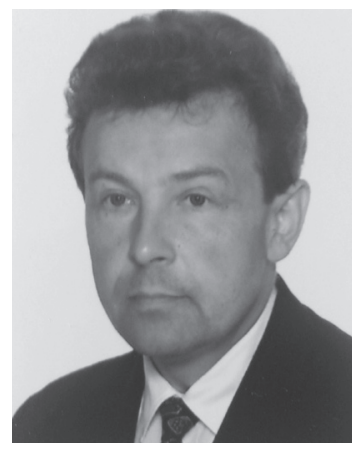

Dr hab. Artur Znajomski pracuje w Instytucie Informacji Naukowej i Bibliotekoznawstwa UMCS w Lublinie. Główny nurt jego zainteresowań badawczych to zagadnienia bibliografii osobowych i bibliografii lokalnych w Polsce. Ważniejsze publikacje: Bibliografie osobowe historyków polskich (Lublin 2004), Bibliografie zespołów osobowych - instytucji, stan i potrzeby. W: Bibliografia: teoria, praktyka, dydaktyka. Red. J. Woźniak-Kasperek, M. Ochmański (Warszawa 2009); Wpływ lwowskiego środowiska historycznego na rozwój metodyki bibliografii osobowej do roku 1939. W: Wielokuturowe środowisko historyczne Lwowa w XIX $i$ XX w. T. 5. Red. J. Maternicki i L. Zaszkilniak (Rzeszów 2007); Bibliografie specjalne - tendencje rozwoju na przykładzie bibliografii osobowych. W: Piata Ogólnokrajowa Narada Bibliografów (Warszawa 2004); The state of local bibliographies in Poland after World War II. W: Around the Book the Library and Information. Ed. M. Juda (et al.) (Lublin 2014); Sprawność informacyjna bibliografii lokalnych wydanych w Polsce w latach 1945-1989. W: Dymmel A., Kotuła S. D., Znajomski A.: Kultura czytelnicza i informacyjna - teoria i praktyka. Wybrane zagadnienia (Lublin 2015); Zarys rozwoju polskich bibliografii lokalnych do 1939 roku. W: Bibliografi@. Historia, teoria, praktyka. Red. J. Franke, J. Woźniak-Kasperek (Warszawa 2016). Jest autorem i współautorem szeregu opracowań bibliograficznych m.in. Bibliografii publikacji prof. dr hab. Barbary Trelińskiej za lata 1973-2012. W: Między tekstem a znakiem (Warszawa 2013), współredaktorem Bibliografii miasta Świdnika do roku 2003 (Świdnik 2004).

SŁOWA KLUCZOWE: Bibliografie lokalne. Ocena. Recenzje.

ABSTRAKT: Tezy/cel artykułu - Podstawowym celem artykułu jest prezentacja zagadnień podejmowanych w recenzjach bibliografii lokalnych. Metody badań - Zastosowano metodę krytyki i analizy recenzji poświęconych polskim bibliografiom lokalnym o charakterze ogólnym. Wyniki i wnioski - Recenzje poruszają szereg ważkich problemów 
związanych z doborem i selekcją materiału, opisem, układem, aparatem informacyjno-pomocniczym oraz ukształtowaniem typograficznym bibliografii. Przeprowadzone badania dowodza, że przeważająca część ocenianych spisów posiada różnego typu mankamenty natury metodycznej i edytorskiej. W celu ich wyeliminowania należy częściej poddawać je ocenie specjalistów i to już na etapie przygotowania wydawniczego.

\section{UWAGI WSTĘPNE}

Bibliografie lokalne zostały zapoczątkowane w Polsce w pierwszej połowie XIX w. przez Józefa Ignacego Kraszewskiego ${ }^{1}$. Na przestrzeni swojej 180-letniej historii były niejednokrotnie obiektem zainteresowania ze strony krytyków. Wielokrotnie poddawano je rozmaitym analizom i ocenom, w których prezentowano ich zalety, jak też ukazywano różne mankamenty i niedoskonałości.

Podjęty temat nie był dotychczas przedmiotem badań, chociaż recenzje zajmują ważne miejsce $\mathrm{w}$ piśmiennictwie naukowym oraz pełnią szereg istotnych funkcji. Informują o ukazaniu się publikacji, oceniają je, korygują dostrzeżone błędy, uzupełniają recenzowane dzieła o pominięte treści oraz inspirują do dalszych badań. Świadczą także o prestiżu publikacji i są oznaką poważania dla jej autora (Żbikowska-Migoń, 2008, s. 145-146). Zasadne zatem wydaje się poruszenie problemu oceny i recepcji bibliografii lokalnych przez specjalistów.

Celem artykułu jest pokazanie obrazu bibliografii lokalnych o charakterze ogólnym, jaki wyłania się z opinii krytyków, zwrócenie uwagi na zagadnienia intrygujące recenzentów oraz przyjrzenie się, $\mathrm{w}$ jakim stopniu ich sugestie i zalecenia były respektowane przez autorów bibliografii.

Materiał źródłowy został zebrany w głównej mierze na podstawie retrospektywnych i bieżących polskich bibliografii dostępnych w tradycyjnej wersji drukowanej oraz $\mathrm{w}$ postaci elektronicznej, obejmujących lata 1625-2010. W wyniku przeprowadzonych poszukiwań zgromadzono 47 recenzji, wydanych w latach 1913-2009, odnoszących się do 14 bibliografii lokalnych. Dotyczyły one bibliografii lokalnych przedmiotowych oraz spisów o charakterze podmiotowym. Oceniano przede wszystkim zestawienia retrospektywne wydane w postaci książek.

Największym zainteresowaniem ze strony krytyków cieszyła się monumentalna, ośmiotomowa Bibliografia Warszawy (Warszawa 1958-2006). Doczekała się ona aż czternastu recenzji. Dużo uwagi poświęcono także bibliografiom lokalnym autorstwa Henryka Baranowskiego, tj. dwutomowej, retrospektywnej Bibliografii miasta Torunia (Warszawa-Poznań 1972; Toruń 1996) oraz trzytomowej Bibliografii Wilna (Torun 1996-2007). Pierw-

\footnotetext{
${ }^{1}$ Za pierwszą poważniejszą bibliografię lokalną na gruncie polskim uznaje się Bibliografię druków wileńskich autorstwa J. I. Kraszewskiego, opublikowaną w 1842 r. w IV tomie jego monografii Wilno od początków jego do roku 1750 (Matczuk, Znajomski, 2015, s. 151-152; Znajomski, 2015b, s. 49).
} 
sza z nich legitymuje się siedmioma recenzjami, a druga pięcioma. Spore zaciekawienie wzbudzało również zestawienie Ksiażki o Krakowie. Wybór publikacji z lat 1945-1969 (Kraków 1971), przygotowane przez Teresę Bieńkowską i Zdzisławę Vogel. Spis ten był trzykrotnie oceniany. Pozostałe bibliografie posiadają jedną bądź dwie recenzje.

Recenzje bibliografii lokalnych ogłaszano z reguły w czasopismach naukowych. Swoje łamy udostępniały dla nich często renomowane czasopisma bibliologiczne, historyczne i regionalne, m.in. „Roczniki Biblioteczne”, „Przegląd Biblioteczny”, ,"Kwartalnik Historyczny”, , Studia Źródłoznawcze”, ,Archeion”, ,Zapiski Historyczne”, ,Res Historica”, ,Rocznik Warszawski”, ,Rocznik Łódzki”. Pojawiały się również na szpaltach tygodników, a nawet dzienników i, co warto podkreślić, nie zawsze przybierały formę sprawozdawcza, jak to najczęściej bywa praktykowane. Niektóre z nich mają postać krytycznych artykułów o cechach naukowych, ostro oceniających mankamenty analizowanych prac bibliograficznych (Gomulicki, 1959, s. 6-7). Swego rodzaju ewenementem, ze względu na miejsce publikacji, jest recenzja Bibliografii Warszawy, którą autor wkomponował w rozprawę omawiającą dzieje książek poświęconych stolicy Polski (Gomulicki, 1961, s. 143-147).

Autorami recenzji byli najczęściej bibliografowie i historycy. W gronie recenzentów znaleźli się wybitni znawcy zagadnień bibliograficznych, praktycy, teoretycy i badacze dziejów bibliografii, jak: Ksawery Świerkowski, Konrad Zawadzki, Maria Szymańska, Alicja Matczuk oraz wytrawni historycy, nierzadko o inklinacjach bibliograficznych, m.in. Gerard Labuda, Marian Tyrowicz, Jerzy Serczyk, Marceli Kosman, Witold Maisel, Zdzisław Budzyński.

W swoich opiniach podnosili oni szereg istotnych kwestii metodycznych i metodologicznych. Poruszali sprawy ważkie z punktu widzenia doboru i selekcji materiału oraz rozwoju i doskonalenia metodyki bibliografii lokalnych. Podejmowali problem opisu, układu i aparatury informacyjno-pomocniczej. Zwracali uwagę na kompozycję wydawniczą bibliografii (tytulaturę, przedmowy, wykazy skrótów, spisy tytułów czasopism i ich skrótów, indeksy), jej ukształtowanie typograficzne, formę językową oraz wszelkiego rodzaju dodatki do spisu (aneksy, wykazy wykorzystanych źródeł, tablice, streszczenia obcojęzyczne itp.).

\section{DOBÓR I SELEKCJA MATERIAŁU}

Dobór materiału odgrywa niezmiernie ważną rolę w każdym typie bibliografii, bowiem decyduje on w głównej mierze o ich wartości użytkowej. Recenzenci niemal każdej bibliografii lokalnej sporo miejsca poświęcali temu zagadnieniu. 
Główna odpowiedzialność za dobór i selekcję piśmiennictwa oraz metodę opracowania bibliografii spoczywa na autorach spisów. Od ich wiedzy i doświadczenia zależy poziom merytoryczny i ostateczny kształt każdej bibliografii. O kompetencji twórców mówili nieraz krytycy bibliografii lokalnych. Sprawę tę podjęto już w jednej z pierwszych recenzji, którą poświęcono bieżącej Bibliografii Krakowa za rok 1912, autorstwa Kazimierza Kaczmarczyka. Recenzent, chwaląc wydane zestawienie, wskazał na potrzebę stworzenia wysiłkiem zbiorowym retrospektywnej bibliografii Krakowa, ale zaznaczył, że należy ją opracować "(...) pod jednolitym kierunkiem fachowego historyka-bibliografa" (P., 1913, s. 2).

Brak profesjonalnego kierownictwa oraz niekompetencja części współautorów w zakresie znajomości przedmiotu były zdaniem recenzentów główną przyczyną niepoprawnego opracowania pierwszego tomu $\mathrm{Bi}$ bliografii Warszawy, obejmującego druki zwarte. Juliusz W. Gomulicki, poszukując odpowiedzi na pytanie o powody „(..) niedopuszczalnych mankamentów bibliograficznych, deprecjonujących całe dzieło i kompromitujących jego protektorów" (Gomulicki, 1959, s. 6), uważał, że wpływ na to miały „(...) niewysokie, niestety, kwalifikacje «varsavianistyczne» kierownictwa redakcji (słaba znajomość problematyki i słaba znajomość dzieł)" (Gomulicki, 1959, s. 6). Opinię tę w pełni podzielał K. Świerkowski, który stwierdził jednoznacznie, że "Za całość odpowiada (...) redaktor" (Świerkowski, 1959, s. 1297). W celu wyeliminowania nieprawidłowości w kolejnych tomach bibliografii Warszawy, obaj krytycy wskazywali na konieczność włączenia do pracy specjalistów i konsultantów do poszczególnych działów, ponoszących pełną odpowiedzialność za ich przygotowanie. Ponadto postulowali opracowanie przez redakcję instrukcji dla współpracowników, która pozwoliłaby skorygować ewentualne błędy i przez to zapewniłaby bibliografii odpowiedni poziom (Gomulicki, 1959, s. 6; Szwejcerowa, 1960, s. 242; Gruca, 2013, s. 162).

Fundament każdej bibliografii stanowi odpowiednio dobrany materiał źródłowy. Większość recenzentów na ogół bardzo pozytywnie wyrażała się o trudzie i wkładzie pracy autorów bibliografii w gromadzenie podstawy źródłowej. Z dużym uznaniem mówili o liczbie i różnorodności wykorzystanych źródeł informacji i opracowań, szeroko zakrojonych kwerendach bibliograficznych, bibliotecznych i archiwalnych, podejmowanych nie tylko w Polsce, ale też poza jej granicami. Niektórzy jednak dostrzegali braki w rejestrowanym materiale, za co krytykowali twórców bibliografii (Rosin, 1987, s. 312-313; Długokęcki, 1992, s. 75). Winą za zaistniały stan rzeczy obarczali nie tyle autorów spisów, co przyczyny obiektywne. Gerard Labuda, poruszając kwestię uzupełnień, stwierdził, że „(...) najdokładniejsza kwerenda przed nimi nie uchroni" (L[abuda], 1976, s. 266). Myśl tę podzielał Sławomir Łowkis. Uważał on, iż "Jest oczywiste, że pominięcia są nieuniknione, te zamierzone i te niezamierzone" (Łowkis, 
2002, s. 11). Stąd wydane bibliografie były dla niektórych krytyków inspiracją do ich dopełniania. Szczególną troskę w tym względzie wykazał S. Łowkis. Przy okazji oceny Bibliografii Wilna, wzbogacił to dzieło o 54 nowe pozycje, nieznane autorowi spisu (Łowkis, 2002, s. 11-12). Inni recenzenci wymieniali z reguły od jednej do kilku nowych prac, przeważnie z zakresu swojej specjalności naukowej.

Bibliografie lokalne, w zależności od rodzaju, stosują odmienne kryteria doboru i selekcji materiału. Bibliografie lokalne przedmiotowe koncentrują się na treści rejestrowanych dokumentów. Ich celem jest ukazanie miast i mniejszych miejscowości w jak najszerszym wymiarze, we wszystkich dziedzinach i przejawach życia. Natomiast spisy podmiotowe za podstawę doboru publikacji przyjmują cechy wydawniczo-typograficzne gromadzonego piśmiennictwa. Przeważnie zestawiają dzieła o określonej formie wydawniczej (np. książki), bądź uwzględniają jedynie wybrany typ dokumentu.

W przypadku bibliografii przedmiotowych uwaga recenzentów skierowana była przede wszystkim na zasięg wydawniczo-formalny poszczególnych zestawień. Docenili oni dobór nie tylko publikacji samoistnych pod względem wydawniczym (wydawnictw zwartych i ciągłych) oraz utworów bibliograficznych (artykułów z czasopism i rozpraw z dzieł zbiorowych), ale też fragmentów bibliograficznych (Maisel, 1974, s. 124; Matczuk 1996/1997, s. 119).

Za celowe uznali także uwzględnianie artykułów prasowych, pomijanych na ogół przez inne rodzaje bibliografii. Autorzy recenzji jednogłośnie stwierdzili, że bibliografie lokalne przedmiotowe powinny je wykazywać. Bowiem, jak się wyraził J. Serczyk, „Bez Bibliografii pamięć o nich zanikłaby bardzo szybko - dzięki niej mają szansę pozostania w obiegu informacyjnym" (Serczyk, 1997, s. 269).

W pełni zaakceptowali również rejestrację rozmaitych form piśmienniczych, publikacji naukowych, popularnonaukowych, popularnych, dokumentacyjnych i informacyjnych. Zastrzeżeń nie budził dobór prac współautorskich, redakcyjnych, edytorskich, tłumaczeń, wywiadów, recenzji, bibliografii, przewodników, encyklopedii, słowników, informatorów, uchwał i zarządzeń, pamiętników, wspomnień, listów oraz biografii (Maisel, 1974, s. 124; Andrzejewski, 1978, s. 340-341).

U niektórych krytyków wątpliwości rodził jedynie dobór utworów literackich opisujących daną miejscowość. W. Maisel, jeden z recenzentów Bibliografii miasta Torunia, miał pewne zastrzeżenia, co do słuszności uwzględniania w bibliografii lokalnej dzieł literackich, ostatecznie jednak przyznał, „(...) że dla miłośników miasta zgromadzenie tego rodzaju informacji w jednym dziele bibliograficznym może być użyteczne" (Maisel, 1974, s. 124).

Rozstrzygnięcie tego zagadnienia nie jest sprawą prostą. Wydaje się, że nie można wyeliminować literatury pięknej, zwłaszcza, że użytkowni- 
kami bibliografii są zwykle osoby o różnorakich zainteresowaniach, poszukujące materiałów nie tylko o charakterze naukowym, czy popularnonaukowym. Nadto, twórczość literacka stanowi z jednej strony, probierz zainteresowania pisarzy danym miastem, z drugiej zaś, może być cennym materiałem badawczym dla literaturoznawców.

Recenzenci pozytywnie wyrażali się o doborze różnych typów dokumentów, nie tylko piśmienniczych, ale też kartograficznych, ikonograficznych oraz dokumentów życia społecznego. Obok dokumentów drukowanych podkreślali wagę i znaczenie, uwzględnianych przez bibliografie, prac niepublikowanych, zwłaszcza doktorskich i magisterskich. Bowiem, jak trafnie zauważyła A. Matczuk, „Stanowią one często ważne, a niekiedy jedyne źródło informacji rzeczowej (dysertacje) oraz bibliograficznej, przez co ułatwiają prowadzenie kwerendy archiwalno-bibliotecznej" (Matczuk, 1996/1997, s. 119).

Autorzy recenzji pochlebnie ocenili zestawienia o nieograniczonym zasięgu językowym. Dotyczyło to m.in. bibliografii Łodzi, Szczecina, Torunia i Wilna. Niewątpliwie z tą oceną trzeba się zgodzić, gdyż zawężenie omawianego zasięgu do publikacji w jednym języku znacznie zuboża i deformuje bibliograficzny wizerunek życia miasta, a w przypadku bibliografii podmiotowych nie oddaje całego obrazu produkcji wydawniczej danego ośrodka. Podkreśliła to A. Matczuk w omówieniu zestawienia Druki przemyskie 1754-1939, które zacieśniło zasięg językowy do druków wydanych alfabetem łacińskim, pomijając cały szereg druków ukraińskich opublikowanych alfabetem cyrylickim oraz żydowskich ogłoszonych po hebrajsku (Matczuk, 2007, s. 211-212).

Recenzenci bibliografii lokalnych podmiotowych, w przeciwieństwie do krytyków spisów przedmiotowych, w niewielkim stopniu zajmowali się zasięgiem wydawniczo-formalnym. Z pewnością wynikało to z faktu, że był on zgodny z wytycznymi przyjętymi w praktyce bibliograficznej. Zestawienia podmiotowe dokumentowały rozmaite wytwory produkcji wydawniczej poszczególnych ośrodków. Część spisów, jak np. zestawienie Druki toruńskie XVI wieku (Warszawa 1969), opracowane przez Leonarda Jarzębowskiego, czy Bibliografia druków elblaskich 1558-1772, autorstwa Jerzego Sekulskiego, rejestrowały wyłącznie stare druki. Inne zaś, jak choćby Bibliografia łódzkiej produkcji wydawniczej (do 1918 r.) (Łódź 1975), przygotowana przez Janinę Jaworską, uwzględniały bardzo szeroki wachlarz publikacji (książki, broszury, czasopisma, kalendarze, mapy, nuty oraz dokumenty życia społecznego), starając się pokazać cały dorobek wydawniczy miasta.

Krytycy domagali się doprecyzowania zasięgu chronologicznego niektórych bibliografii podmiotowych. Wiesław Długokęcki $\mathrm{w}$ recenzji Bibliografii druków elbląskich 1558-1772, uznał dolną granicę zasięgu chronologicznego za wątpliwa, ponieważ wśród badaczy brak było jed- 
noznacznego stanowiska odnośnie daty wydania pierwszego druku elbląskiego; jedni uważali, że był to rok 1557, inni zaś przyjmowali rok 1558 (Długokęcki, 1992, s. 74). Z kolei Ryszard Rosin domagał się uściślenia górnej granicy zasięgu chronologicznego Bibliografii łódzkiej produkcji wydawniczej. 1918-1939. Słusznie zauważył „Wybuch II wojny światowej i początki okupacji hitlerowskiej bardzo szybko doprowadziły do poważnego ograniczenia łódzkiej produkcji wydawniczej oraz jednocześnie jej jakościowego przeobrażenia. Rzeczywistą górną granicą powinien być zatem, w tym przypadku, początek września 1939 r., a to co wyszło później, na przykład nowe wydawnictwa niemieckie (...) należało zaliczyć już do okresu okupacji" (Rosin, 1987, s. 313).

Rozważając sprawy kompletności bibliografii lokalnych, recenzenci zgodnie stwierdzili, że nie są one kompletne. Dostrzegli jednak, że niektóre zestawienia, głównie podmiotowe, chcąc zobrazować rozwój całego dorobku wydawniczego danej miejscowości, dążyły do kompletności w doborze materiału. Natomiast bibliografie przedmiotowe stosowały selekcję i to zarówno formalna, jak i merytoryczną.

Ogólne zasady selekcji formalnej stosowane w bibliografiach lokalnych przedmiotowych nie były podważane przez krytyków. Kwestionowali oni jednak $z$ jednej strony, pomijanie przez bibliografie niektórych form piśmienniczych, z drugiej zaś, włączanie określonych typów dokumentów. Można jednak zauważyć, że na ogół krytycy nie byli zwolennikami stosowania selekcji według formy wydawniczej. Dla przykładu, recenzent zestawienia Ksiązki o Krakowie. Wybór publikacji z lat 1945-1969, ubolewał z powodu pominięcia artykułów z czasopism, dotyczących dawnej stolicy Polski (B.W., 1971, s. 624). Należy się z nim zgodzić, ponieważ bibliografia lokalna przedmiotowa powinna uwzględniać wszystkie jednostki bibliograficzne, aby nie narażać użytkowników na dodatkowe żmudne i czasochłonne poszukiwania materiałów nie uwzględnionych w spisie.

Zdzisław Budzyński, omawiając Materiały do bibliografii Przemyśla, żałował, że autorzy spisu nie uwzględnili biogramów wybitnych przemyślan, zamieszczonych w Polskim słowniku biograficznym, które znacząco wzbogaciłyby dział biograficzny bibliografii (Budzyński, 1985, s. 184). Z kolei Bibliografia Warszawy, obejmująca druki zwarte, rejestrowała wprawdzie artykuły z Polskiego słownika biograficznego, ale czyniła to niekonsekwentnie, co zauważył i podkreślił M. Tyrowicz (1959, s. 242).

Nie ulega wątpliwości, że dział biograficzny w bibliografii lokalnej przedmiotowej odgrywa ważną rolę, ponieważ prezentuje wybitne i zasłużone osoby, które zapisały się w dziejach miasta lub miejscowości, przyczyniły się do jego rozwoju w różnych dziedzinach życia bądź rozsławiły swoje miasto. Stanowi on niewątpliwie dumę społeczności lokalnej i utrwala pamięć o tych osobach, a dla badaczy jest ważnym i nieocenionym źródłem informacji. Niekompletność działu biograficznego nie daje 
pełnego i właściwego obrazu danego miasta, widzianego przez pryzmat losów jednostek.

Witold Maisel natomiast uznał, iż Bibliografia miasta Torunia niepotrzebnie zarejestrowała materiały rękopiśmienne, dla których miejsce widział w inwentarzach i katalogach archiwalnych. Zaakceptował jednak włączenie do spisu maszynopisów prac magisterskich oraz niedrukowanych prac wykonanych przez Pracownię Konserwacji Zabytków w Toruniu (Maisel, 1974, s. 124; Gruca 2013, s. 164).

Z kolei Aniela Szwejcerowa za błąd uznała włączenie do Bibliografii Warszawy, zestawiającej druki zwarte, odbitek i nadbitek z czasopism. Swoje stanowisko uzasadniała tym, że „Odbitki są materiałem z czasopism i jest tylko kwestią przypadku, że akurat poszczególne tylko pozycje z określonych czasopism trafiły do autorów bibliografii. Teoretycznie bowiem każdy artykuł drukowany w czasopiśmie naukowym może się znaleźć $\mathrm{w}$ zbiorach $\mathrm{w}$ formie odbitki lub nadbitki. Tym bardziej jest to błędne i nieuzasadnione, że autorzy w planie prac przewidują opracowanie specjalnego tomu zawierającego materiały z czasopism" (Szwejcerowa, 1960, s. 244).

Aby selekcja wartościująca była poprawnie przeprowadzona, na wstępie pracy należy jasno określić jej kryteria. Recenzenci spostrzegli, że nie wszystkie bibliografie lokalne respektowały tę wskazówkę metodyczną, co w konsekwencji bardzo negatywnie odbijało się na ich wartości użytkowej. Niesprecyzowanie zasad selekcji w Bibliografii Warszawy, zestawiającej druki zwarte, spowodowało, zdaniem recenzenta, „(...) pominięcie wielu podstawowych, jeśli chodzi o varsaviana, pozycji bibliograficznych [oraz] rejestrowanie pozycji nie mających nic wspólnego z tematyką warszawską" (Gomulicki, 1965, s. 6).

O selekcji merytorycznej recenzenci mówili przede wszystkim przy okazji doboru artykułów prasowych. Tego typu publikacje, zdaniem opiniodawców, powinny być poddane selekcji merytorycznej. Nie wszystkim jednak bibliografiom udało się ją dobrze przeprowadzić. Brak ostrej selekcji w stosunku do artykułów z prasy codziennej był jednym z mankamentów Bibliografii Warszawy, uwzględniającej zawartość wydawnictw ciągłych. Zdaniem K. Zawadzkiego „Sposób przeprowadzenia (...) selekcji nasuwa (...) poważne zastrzeżenia, w Bibliografii bowiem uwzględniona została ogromna ilość drobnych wzmianek reporterskich, notatek o sensacyjnych „rewolwerowych” tytułach, w treści swej niczego właściwie poza tymi tytułami nie wnoszących, niewiele znaczących informacji, w których powodzi trudno odszukać materiał naprawdę cenny" (Zawadzki, 1965a, s. 293). Podobną opinię wyraziła Halina Zaręba, która dodatkowo stwierdziła, że "Włączenie do Bibliografii bardzo drobnych artykułów z dzienników (...) powiększyło jej objętość" (Zaręba, 1965, s. 246).

Selekcja merytoryczna, choć niełatwa do przeprowadzenia, powinna być oczywiście stosowana, ale trzeba ją odpowiednio wyważyć. Pomija- 
nie drugorzędnych artykułów prasowych o nikłej wartości jest bez wątpienia zasadne i potrzebne. Nie może ona jednak wykluczać publikacji naukowych, a nawet artykułów z gazet, jeśli są one ważne dla odbiorcy bibliografii. Przeprowadzenie selekcji merytorycznej nie jest łatwe, wymaga bowiem dobrej znajomości przedmiotu i nie da się tutaj ustalić ogólnej receptury.

\section{OPIS BIBLIOGRAFICZNY}

W ocenie opisu bibliograficznego recenzenci koncentrowali się głównie na jego prymarności. Krytycy dopuszczali wprawdzie opisy pochodne, ale przy niektórych typach dokumentów domagali się badania ich z autopsji, bowiem dzięki niej można wprowadzić uzupełnienia i poprawki do znanych już opisów bibliograficznych, a ponadto umożliwia ona identyfikację nieznanych wcześniej druków. Brak autopsji był jednym z głównych zarzutów stawianych przez recenzentów Bibliografii starych druków kaliskich do końca XVIII wieku (Warszawa-Poznań 1980), przygotowanej przez Krystynę Bielską. Jan Sójka stwierdził, że zastosowanie przez autorkę opisu pochodnego i ogłoszenie go w formie skróconej, nie tylko obniżyło wartość informacyjną bibliografii, ale też „(...) nadaje zrębowi głównemu tej publikacji charakter inwentarza produkcji kaliskiej do końca XVIII wieku lub drukowanego katalogu centralnego druków kaliskich, może rejestru lub wykazu produkcji, ale z pewnością nie bibliografii sensu stricto" (Sójka, 1982, s. 368). Z tą opinią zgodziła się Maria Cubrzyńska-Leonarczyk. Ponadto sądziła ona, że opisy $z$ „drugiej ręki” nie wnoszą niczego nowego do badań nad drukarstwem kaliskim. Są jedynie odwzorowaniem kart katalogowych, powielają istniejące $\mathrm{w}$ nich błędy. Nie wyjaśniają kwestii wątpliwych, odnoszących się do poszczególnych wariantów, czy też kolejnych edycji starych druków (Cubrzyńska-Leonarczyk, 1982, s. 377-383). Nie spełniają zatem należycie swojej podstawowej funkcji, polegającej na identyfikacji dokumentu.

Odstąpienie od autopsji w opisie druków zwartych było również jednym z czynników deprecjonujących Bibliografię Warszawy. J.W. Gomulicki wskazał, że w dziele są „(...) nieprecyzyjne opisy bibliograficzne (prawie zawsze np. brak w nich informacji o ilustracjach), pomijające b. często zasadnicze elementy informacyjne (nazwisko autora, datę wydania, ilość stronic) [oraz] fałszywe opisy bibliograficzne (przekręcone nazwiska autorów i tytuły dzieł, mylne daty wydania, a nawet pozycje nieistniejące)" (Gomulicki, 1959, s. 6). W podobnym tonie wypowiedział się K. Swierkowski (1959, s. 1296). Autopsja pozwoliłaby z pewnością wyeliminować tego typu pomyłki.

Omawianego błędu ustrzegł się spis Druki przemyskie 1754-1939. Cechuje go wysoki stopień prymarności. Autopsja pozwoliła autorce bibliografii 
ustalić takie elementy opisu, jak: format, nakład czy dodatki do tekstu. Umożliwiła rozwiązanie kryptonimów, pseudonimów i inicjałów imion twórców publikacji. Przyczyniła się również do ustalenia autorstwa dzieł anonimowych oraz przytaczania pełnych tytułów zarejestrowanych prac. Za to wszystko bibliografia otrzymała pozytywną notę od kompetentnej recenzentki (Matczuk, 2007, s. 212).

Niektórzy krytycy poruszali sprawę normalizacji opisów bibliograficznych. Pochlebnie wyrażali się o bibliografiach, stosujących opisy znormalizowane. J. Serczyk stwierdził, że dostosowanie opisu książek do zasad ISBD w Bibliografii miasta Torunia przyczyniło się do jej umiędzynarodowienia (Serczyk, 1997, s. 268). Natomiast A. Matczuk, oceniająca tę samą pracę, chociaż nie podważała zasadności normalizacji opisów, uważała jednak, że wobec istnienia dwóch różnych norm - nowej, międzynarodowej dla opisu książek, i normy opartej na przepisach polskich, dotyczącej artykułów z czasopism, autor bibliografii powinien ujednolić opis i dostosować go do zasad wcześniej w Polsce obowiązujących. Dzięki takiemu zabiegowi zostałaby utrzymana jednolitość metodyczna między obydwoma tomami Bibliografii miasta Torunia (Matczuk, 1996/1997, s. 119).

Na temat normalizacji zapisu wypowiedział się także Z. Budzyński. Zasugerował on twórcom bibliografii Przemyśla wprowadzenie norm używanych w bibliografiach retrospektywnych, tj. PN-56/N-01156: 1956. Przepisy bibliograficzne - Opis zasadniczy w bibliografii retrospektywnej dziedzin lub zagadnień oraz PN-56/N-01155: 1956. Przepisy bibliograficzne - Skrócony opis bibliograficzny (Budzyński, 1987, s. 183).

Recenzenci krytykowali niekonsekwencje w opisach bibliograficznych, zmiany kolejności elementów opisu, pomijanie niektórych składników, niejednolite stosowanie znaków przestankowych itp. Dotyczyło to m.in. Bibliografii starych druków kaliskich, zestawienia Druki toruńskie XV wieku oraz dwóch pierwszych tomów Bibliografii Warszawy (Cubrzyńska-Leonarczyk, 1982, s. 378; Nowak, 1970, s. 1113; Świerkowski, 1959, s. 1296; Zaręba, 1965, s. 247). Za niedopuszczalną praktykę uważali powtarzanie tych samych opisów w różnych miejscach bibliografii (Jasińska, 1959, s. 158).

Z uznaniem wypowiadali się natomiast o bibliografiach dopełniających opis zasadniczy adnotacjami. Jerzy K. Andrzejewski, opiniując Bibliografię łódzkiej produkcji wydawniczej (do 1918 r.), przyznał, że "Cennym elementem opisu jest (...) zastosowanie adnotacji księgoznawczych podających informacje o kolejnych wydaniach, przekładach, wersjach wielojęzycznych, zmianach tytułów, drukarzy wydawców. Podawanie przy każdym opisie dokumentu sigla biblioteki, w której dany druk się znajduje, sprawia, że bibliografia ta spełnia jednocześnie rolę centralnego katalogu druków łódzkich" (Andrzejewski, 1978, s. 342).

Niektóre zestawienia, m.in. Druki przemyskie 1754-1939, Bibliografia Wilna oraz Bibliografia miasta Torunia, były także dobrze ocenione za wpro- 
wadzenie adnotacji - i to nie tylko księgoznawczych, ale też treściowych, najczęściej wyjaśniających i zawartościowych (Matczuk, 2007, s. 212-213; Dubowik, 2001, s. 17; Maisel, 1974, s. 124). Temu ostatniemu spisowi W. Maisel nadał nawet miano „bibliografii rozumowanej” (Maisel, 1974, s. 124).

Nie można było tego powiedzieć o Bibliografii Warszawy, uwzględniającej druki zwarte. Zdaniem recenzentów, nie została ona wyposażona w odpowiednią liczbę adnotacji. Ponadto te, które wprowadzono, uzupełniały niewłaściwe opisy oraz były źle zredagowane (Gomulicki, 1959, s. 6; Świerkowski, 1959, s. 1296).

\section{UKŁAD BIBLIOGRAFII}

Układowi bibliografii najwięcej uwagi poświęcili krytycy Bibliografii Warszawy. Wybór układu systematycznego jako podstawy porządkowania materiału w zrębie głównym uznali za właściwy i uzasadniony, bowiem dobrze oddawał on poszczególne dziedziny życia miasta. Nie zaakceptowali jednak struktury wewnętrznej poszczególnych działów. Uważali ją za zbyt rozbudowaną, wymagającą uściślenia. Zdaniem K. Zawadzkiego, zamiast drobiazgowego dzielenia działów zasadniczych na poddziały pierwszego i dalszych rzędów, lepszym rozwiązaniem byłoby zwiększenie liczby działów głównych, co dodatnio wpłynęłoby na sprawność informacyjną całego spisu (Zawadzki, 1965, s. 294).

Aprobaty nie zyskał również układ wewnętrzny zastosowany w Bibliografii Warszawy rejestrującej artykuły z czasopism. Według H. Zaręby skomplikowane połączenie układu chronologicznego z układem alfabetycznym należało zastąpić układem rzeczowym, o wiele dogodniejszym dla użytkownika (Zaręba, 1965, s. 247; Znajomski, 2015b, s. 122-123).

Niezbyt pochlebne opinie zebrał także układ, oparty na schemacie klasyfikacji dziesiętnej, przyjęty w spisie Druki przemyskie 1754-1939. Recenzentka dostrzegła, że w tym przypadku o wiele korzystniejszy byłby mniej szczegółowy układ rzeczowy złożony z kilkunastu działów głównych, a w ich obrębie zamiast szeregowania alfabetycznego należało wprowadzić układ chronologiczny. Dzięki takim modyfikacjom układu zrębu głównego i porządkowania wewnętrznego poprawie uległaby przejrzystość i percepcja bibliografii (Matczuk, 2007, s. 213-214).

Recenzenci pozostałych bibliografii wypowiadali się na ogół pozytywnie o stosowanych w nich zasadach porządkowania materiału. Na przykład J.K. Andrzejewski, oceniając Bibliografię tódzkiej produkcji wydawniczej (do 1918 r.), zaznaczył, że „Zastosowany przez J. Jaworską układ logiczny narzucił zgromadzony materiał. Okazał się on uzasadniony i sprawił, że korzystanie z bibliografii jest wyjątkowo łatwe i bardzo praktyczne" (Andrzejewski, 1978, s. 342). 
Z porządkowaniem materiału wiąże się sprawa odpowiedniego przydziału publikacji do poszczególnych działów bądź poddziałów. Z opinii krytyków wynika, że większość bibliografii miała z tym duży problem. Niejednokrotnie zdarzały się opisy niewłaściwie sklasyfikowane. Wszelkie tego typu uchybienia były zdecydowanie krytykowane przez recenzentów (Świerkowski, 1959, s. 1296; Szwejcerowa, 1960, s. 158; Szwankowski, 1971, s. 107-108).

Autorzy bibliografii stosowali najczęściej jednokrotny przydział pozycji do działów lub poddziałów. Przy takim rozwiązaniu nieodzowne są odsyłacze. Nie zajmują one wiele miejsca, a ułatwiają czytelnikowi korzystanie z bibliografii. Nie wszystkie jednak zestawienia wprowadziły system odsyłaczy, co oczywiście nie uszło uwadze krytyków (Jasińska, 1959, s. 158-159).

\section{APARAT INFORMACYJNO-POMOCNICZY}

Spośród szeregu materiałów pomocniczych recenzenci najczęściej wypowiadali się na temat indeksu. Nie dziwi to, bowiem indeks, obok układu, ma decydujący wpływ na sprawność informacyjną bibliografii. Stąd wymaga bardzo starannego opracowania. Taką cechą, zdaniem J.K. Andrzejewskiego, legitymują się indeksy dołączone do Bibliografii łódzkiej produkcji wydawniczej (do 1918 r.). Dokonując ich oceny napisał on, że „Bardzo cennym uzupełnieniem pracy są indeksy: Indeks alfabetyczny nazwisk autorów, redaktorów tłumaczy, przedmówców, ilustratorów oraz tytułów prac anonimowych i wydawnictw seryjnych i Indeks przedmiotowy nazw osobowych, geograficznych, firm przemysłowych, instytucji i zrzeszeń, gdzie po raz pierwszy zestawiono w porządku alfabetycznym tak dużą ilość łódzkich instytucji tego okresu. Kapitalny to materiał do wszelkich prac badawczych. Całą pracę zamyka alfabetyczny indeks drukarzy i wydawców, gdzie też po raz pierwszy zestawiono w komplecie łódzkich drukarzy i wydawców działających na przestrzeni 50 lat jej burzliwego rozwoju. (...) Cenne to źródło dla wszelkich poszukiwań dotyczących spraw łódzkiej książki" (Andrzejewski, 1978, s. 343).

Za nienaganne opracowanie chwalono także indeksy dopełniające bibliografie Wilna i Torunia autorstwa H. Baranowskiego (Kosman, 1998, s. 224; Matczuk, 1996/1997, s. 120).

Niestety, znaczna część indeksów nie zyskała tak dobrej oceny. Chociaż nie kwestionowano ich rodzajów, na ogół odpowiednio korespondowały z układem, dobrze go uzupełniając, niektórzy krytycy wskazywali na potrzebę wyposażenia bibliografii w dodatkowe indeksy. Na przykład recenzentki spisu Druki przemyskie 1754-1939 zgodnie postulowały konieczność dodania do bibliografii, obok dwóch istniejących indeksów, tj. autorskiego oraz wydawców, nakładców i współtwórców, indeksu chro- 
nologicznego, pozwalającego zorientować się w przemianach charakteru i struktury tematycznej przemyskiej produkcji wydawniczej. Ponadto skrytykowały indeks wydawców, nakładców i współtwórców książek za to, że brakowało w nim nazw drukarzy i drukarni, wymienionych w opisach zrębu głównego, co pozbawiło użytkowników bibliografii wielu cennych informacji na temat dziejów przemyskiego drukarstwa (Matczuk, 2007, s. 214; Aleksiewicz, 2004, s. 194).

Z kolei K. Zawadzki widział potrzebę wprowadzenia indeksu rzeczowego do Bibliografii Warszawy, rejestrującej artykuły z czasopism, bowiem jego brak „(...) ogranicza w ogromnym stopniu wartość użytkową Bibliografii, powoduje, że tak liczne, niestety, błędnie zaszeregowane opisy stają się pozycjami martwymi" (Zawadzki, 1965, s. 301).

Indeksy miały też szereg błędów metodycznych. Powodowały one, że niektóre indeksy traciły swoją podstawową funkcję, polegającą na pomocy użytkownikowi w sprawnym dotarciu do potrzebnych materiałów. Rażące zaniedbania wykazywał m.in. indeks dołączony do bibliografii Przemyśla. Z. Budzyński w swojej ocenie napisał, że „Indeks nazwisk należałoby (...) powtórnie wydrukować, gdyż brakuje w nim kilkanaście nazwisk (...), niektóre zostały zniekształcone (...) do tego stopnia, że ta sama osoba występuje w dwóch miejscach (...), większość odsyłaczy jest błędna" (Budzyński, 1985, s. 184). Równie surowe noty zebrały dwa indeksy dodane do Bibliografii Warszawy, zestawiającej druki zwarte. K. Świerkowski w podsumowaniu stwierdził, że są one zbyt sformalizowane i zamiast służyć pomocą czytelnikowi, wprowadzają dezinformację (Świerkowski, 1959, s. 1297).

Recenzenci dostrzegli w indeksach także wiele innych niedoskonałości, jak np. niekonsekwencje w opracowaniu edytorskim, błędne odsyłacze, błędy językowe, „literówki” itp. Zdarzały się również indeksy, kierujące użytkownika do numeru strony, czy też szpalty, a nie do określonej pozycji w bibliografii, co niezmiernie utrudniało odbiorcy wyszukiwanie potrzebnych materiałów (Zaręba, 1965, s. 247; Budzyński, 1978, s. 667).

Uwagę krytyków zajmowała również tytulatura bibliografii lokalnych. M. Cubrzyńska-Leonarczyk domagała się zweryfikowania tytułu Bibliografii starych druków kaliskich do końca XVIII wieku. Za błąd logiczny uznała określenie „do końca XVIII wieku”, gdyż z definicji pojęcia "stary druk” wynika, że są to publikacje wydane do 1800 r. (Cubrzyńska-Leonarczyk, 1982, s. 378). M. Tyrowicz przyjrzał się natomiast karcie tyłowej Bibliografii Warszawy, gromadzącej druki zwarte. Uważał, że jest ona niekompletna, bowiem brakowało na niej nazwy redaktora i określenia numeru tomu (Tyrowicz, 1959, s. 241).

Uchybienia dostrzeżono także w spisach treści, przedmowach i wstępach do bibliografii. Zdarzało się, że spisy treści nie odzwierciedlały pełnej budowy bibliografii, a wstępy i przedmowy podawały nieprecyzyjne 
informacje o zasadach opracowania bibliografii. Niekiedy były zbyt obszerne, ale też zdarzały się zbyt lakoniczne i ogólnikowe. Ponadto zawierały błędy stylistyczne, ortograficzne, interpunkcyjne oraz korektorskie. To ostatnie zastrzeżenie formułowano także w stosunku do zrębu głównego i indeksów. Niektórzy recenzenci za wadę bibliografii uznawali brak wykazu skrótów i symboli (Nowak, 1970, s. 1113; Budzyński, 1978, s. 667; Cubrzyńska-Leonarczyk, 1982, s. 381-382).

Pomimo wielu mankamentów i uwag, w konkluzjach krytycy wypowiadali się najczęściej pozytywnie o bibliografiach lokalnych, podkreślając przede wszystkim wartość zgromadzonego materiału. Zachęcali wielu autorów do dalszych prac. Jedynym wyjątkiem była Bibliografia starych druków kaliskich, którą oceniono negatywnie. Motywując swoją decyzję, recenzentka stwierdziła w podsumowaniu, iż „(...) rzecz jest rażąco niedopracowana, widać w niej bardzo dużo usterek redakcyjnych, a wkład autorski często nie jest należycie udokumentowany (...) praca K. Bielskiej nie budzi naszego zaufania, a co gorsza - nie jest w pełni przydatna przy opracowaniu poloników XVII-XVIII wieku czy też uzupełnieniu naszej bibliografii narodowej. Znajdujemy w niej jedynie usystematyzowany chronologicznie materiał do przyszłej bibliografii druków tłoczonych w Kaliszu" (Cubrzyńska-Leonarczyk, 1982, s. 382).

Zdecydowanie odmiennie postrzegano bibliografie lokalne autorstwa H. Baranowskiego. Uznano je za dzieła najstaranniej, modelowo wręcz opracowane (Matczuk, 1996/1997, s. 120; Borzykowski,1997, s. 72).

Oceny bibliografii lokalnych wystawione przez krytyków odbijały się szerokim echem wśród twórców poszczególnych spisów. Niektórzy z nich polemizowali z recenzentami (Redakcja "Bibliografii Warszawy", 1965, s. 302-309; Zawadzki, 1965b, s. 309-311). Inni zaś z pokorą przyjmowali uwagi krytyczne i starali się udoskonalać swoje prace. Jako przykład może posłużyć Bibliografia miasta Torunia. H. Baranowski zgodził się z W. Maiselem w sprawie selekcji prac rękopiśmiennych i nie zamieścił ich w drugim tomie Bibliografii. Pozostawił jedynie, jak już wiemy, maszynopisy prac magisterskich oraz prace wykonane przez Pracownię Konserwacji Zabytków w Toruniu, co recenzent w pełni aprobował (Maisel, 1974, s. 124; Baranowski, 1996, s. XI).

Można sądzić, że pod wpływem krytyki poprawiano również kolejne tomy Bibliografii Warszawy. Od tomu czwartego rejestrującego artykuły z czasopism za lata 1904-1918, zwiększono liczbę działów głównych z jedenastu do dwudziestu (Durko, 1973), czego domagał się, jak wiemy, m.in. K. Zawadzki. Częściej zwracano uwagę na prymarność w gromadzeniu i opisywaniu dokumentów oraz zaostrzano kryteria selekcji. Cecylia Pietrzak, oceniając siódmy tom Bibliografii, stwierdziła, że „Wnikliwa autopsja gazet i czasopism polskich z końca XVIII i połowy XIX w. pozwoliła zebrać materiał obszerny, urozmaicony, bardzo ciekawy, ale przede 
wszystkim o dużej wartości źródłowej, co przy redakcji autorzy starali się wykorzystać. W wyniku selekcji, jakiej został on poddany, do druku weszły pozycje najwartościowsze i najbardziej użyteczne" (Pietrzak, 1996, s. 229). Te korzystne zmiany następowały w związku z zapraszaniem do współpracy specjalistów z poszczególnych dziedzin wiedzy, o co wnioskowali krytycy pierwszych tomów Bibliografii, a potwierdza to opinia Mariana Marka Drozdowskiego (Drozdowski, 2007, s. 382-385).

Nie zawsze jednak krytyczne oceny były respektowane przez bibliografów. Autorzy bibliografii Przemyśla, wydając drugi tom swojej pracy, nie uwzględnili sugestii recenzenta, nie poprawili indeksu, nie wprowadzili też haseł z Polskiego słownika biograficznego (Budzyński, 1978, s. 665-667; Budzyński, 1985, s. 183-185).

\section{PODSUMOWANIE}

Z przeprowadzonych badań wynika, że bibliografie lokalne otrzymywały rozmaite noty od recenzentów. Obok zestawień dobrze przygotowanych, niekiedy stawianych za wzór innym spisom, istniały bibliografie znacznie gorzej opracowane, a nawet zupełnie źle. Ich największym mankamentem były nieprecyzyjne kryteria doboru i selekcji materiału, brak prymarności i niekonsekwencje w opisie bibliograficznym, nieodpowiednia ilość adnotacji, nieprzemyślana konstrukcja układu zrębu głównego, niewłaściwe szeregowanie wewnętrzne, kłopot z przydziałem pozycji do działów, wadliwe indeksy oraz błędy korektorskie.

Aby uniknąć tego typu niedoskonałości, celowe wydaje się wnioskowanie o częstsze recenzowanie bibliografii na etapie opracowania wydawniczego, czym powinni zajmować się odpowiednio przygotowani specjaliści. Dzięki ich opiniom wiele błędów zostałoby z pewnością wyeliminowanych, a praca włożona przez autorów w opracowanie bibliografii i środki finansowe zainwestowane $\mathrm{w}$ ich wydanie nie poszłyby na marne.

\section{BIBLIOGRAFIA}

Aleksiewicz, Anna (2004). (Rec.) Siciak A. Druki przemyskie 1954-1939. Bibliografia publikacji polskich, niemieckich, węgierskich, francuskich oraz żydowskich i ukraińskich wydanych alfabetem łacińskim. Roczniki Biblioteczne R. 48, s. 192-194.

Andrzejewski, Jerzy K. (1978). Łódzka produkcja wydawnicza do 1918 roku. (Rec.) Jaworska J. Bibliografia łódzkiej produkcji wydawniczej (do 1918 r.). Roczniki Biblioteczne R. 22, z. 1/2, s. 340-343.

B.W. (1971). (Rec.) Bieńkowska T., Vogel Z. Książki o Krakowie. Wybór publikacji z lat 1945-1969. Studia Historyczne R. 14, z. 4, s. 624.

Baranowski, Henryk (1996). Wstęp. W: Baranowski H. Bibliografia miasta Torunia. T. 2. 19721993 wraz z uzupetnieniami. Toruń: Towarzystwo Naukowe w Toruniu, s. XI-XII. 
Borzykowski, Józef (1997). (Rec.) Baranowski H. Bibliografia miasta Torunia. T. 2. 19721993 wraz z uzupełnieniami. Pomerania nr 6, s. 72-73.

Budzyński, Zdzisław (1978). (Rec.) Materiały do bibliografii dziejów Przemyśla (19441974). Oprac. Z. Konieczny, J. Motylewicz. Studia Historyczne R. 21, z. 4, s. 665-667.

Budzyński, Zdzisław (1985). (Rec.) Materiały do bibliografii miasta Przemyśla (do roku 1944). Oprac. Z. Konieczny, J. Motylewicz. Rocznik Historyczno-Archiwalny (R.) 2, s. 183-186.

Cubrzyńska-Leonarczyk, Maria (1982). (Rec.) Bielska K. Bibliografia starych druków kaliskich do końca XVIII wieku. Roczniki Biblioteczne R. 26, z. 1/2, s. 377-383.

Długokęcki, Wiesław (1992). (Rec.) Sekulski J. Bibliografia druków elbląskich 1558-1772. Komunikaty Mazursko-Warmińskie [nr] 1, s. 74-76.

Drozdowski, Marian M. (2007). (Rec.) Bibliografia Warszawy. Wydawnictwa ciągłe 19551970. Red. nauk. J. Durko. Rocznik Warszawski (T.) 35, s. 382-385.

Dubowik, Henryk (2001). Bibliografia Wilna - opus magnum Henryka Baranowskiego. [Rec.] Baranowski H. Bibliografia Wilna. T. 2. Miasto. Wileńskie Rozmaitości nr 2, s. 17.

Durko, Janusz, red. (1973). Bibliografia Warszawy. Wydawnictwa ciagłe 1904-1918. Wrocław: Zakład Narodowy im Ossolińskich, Wydaw.

Gomulicki, Juliusz W. (1959). Zmarnowana okazja (o „Bibliografii Warszawy”). [Rec.] Bibliografia Warszawy. Druki zwarte. Red. nauk. J. Durko. Stolica R. 14, nr 22, s. 6-7.

Gomulicki, Juliusz W. (1961). Trzysta lat książki o Warszawie. (Rec.) Bibliografia Warszawy. Druki zwarte. Red. nauk. J. Durko. W: Z dziejów ksiażki i bibliotek w Warszawie. Praca zbior. pod red. S. Tazbira. Warszawa: Państwowy Instytut Wydawniczy, s. 130-202.

Gruca, Anna (2013). Bibliografie historyczne w ocenie czasopism fachowych. W: Bibliografi@. Źródła, standardy, zasoby. Praca zbior. pod red. J. Franke. Warszawa: Wydaw. SBP, s. 161-175.

Jasińska, Maria (1959). (Rec.) Bibliografia Warszawy. Druki zwarte. Red. nauk. J. Durko. Bibliotekarz R. 26, nr 5, s. 156-159.

Kosman, Marceli (1998). (Rec.) Baranowski H. Bibliografia Wilna. T. 1. Uniwersytet Wileński 1579-1939. Zapiski Historyczne T. 63, z. 2, s. 223-224.

L[abuda], G[erard] (1976). (Rec.) Baranowski H. Bibliografia miasta Torunia. Studia Źródłoznawcze [T.] 20, s. 265-266.

Łowkis, Sławomir (2002). Uzupełnienia do Bibliografii Wilna. (Rec.) Baranowski H. Bibliografia Wilna. T. 2. Miasto. Wileńskie Rozmaitości nr 2, s. 11-12.

Maisel, Witold (1974). (Rec.) Baranowski H. Bibliografia miasta Torunia. Zapiski Historyczne T. 39, z. 1, s. 123-125.

Matczuk, Alicja (1996/1997). (Rec.) Baranowski H. Bibliografia miasta Torunia. T. 2. 19721993 wraz z uzupełnieniami. Folia Bibliologica R. 44/45, s. 118-120.

Matczuk, Alicja (2007). (Rec.) Siciak A. Druki przemyskie 1954-1939. Bibliografia publikacji polskich, niemieckich, węgierskich, francuskich oraz żydowskich i ukraińskich wydanych alfabetem łacińskim. Res Historica T. 24, s. 211-214.

Matczuk, Alicja; Znajomski, Artur (2015). Bibliografia lokalna w Polsce - wokół terminu i pojęcia. Przegląd Biblioteczny R. 83, z. 3, s. 349-363.

Nowak, Zbigniew (1970). 400 lat drukarstwa toruńskiego. (Rec.) Druki toruńskie XV wieku. Zebrał i oprac. J. Jarzębowski. Nowe Książki nr 18, s. 1112-1113.

P. (1913). XV. Rocznik Krakowski. (Rec.) Bibliografia Krakowa za rok 1912. Zest. K. Kaczmarczyk. Nowa Reforma R. 32, nr 224, s. 2.

Pietrzak, Cecylia (1996). (Rec.) Bibliografia Warszawy. Wydawnictwa ciągłe 1795-1863. Red. nauk. J. Durko. Archeion T. 96, s. 228-230. 
Redakcja „Bibliografii Warszawy” (1965). [Polem.] Bibliografia Warszawy. Wydawnictwa ciągłe. 1944-1954. Red. J. Durko. Rocznik Warszawski [R.] 6, s. 302-309.

Rosin, Ryszard (1987). (Rec.) Marczyńska M., Żmuda R. Bibliografia łódzkiej produkcji wydawniczej. 1918-1939. Rocznik Łódzki T. 37, s. 311-313.

Serczyk, Jerzy (1997). (Rec.) Baranowski H. Bibliografia miasta Torunia. T. 2. 1972-1993 wraz z uzupełnieniami. Rocznik Toruński T. 24, s. 266-269.

Sójka, Jan (1982). (Rec.) Bielska K. Bibliografia starych druków kaliskich do końca XVIII wieku. Rocznik Kaliski T. 15, s. 3655-368.

Szwankowski, Eugeniusz (1971). Bibliografia Warszawy. Wydawnictwa ciągłe 1864-1903. Red. nauk. J. Durko. Kronika Warszawy [nr] 4, s. 106-109.

Szwejcerowa, Aniela (1960). Uwagi i myśli o pracy „Bibliografia Warszawy”. (Rec.) Bibliografia Warszawy. Druki zwarte. Red. nauk. J. Durko. Nauka Polska R. 8, nr 1, s. 241-245.

Świerkowski, Ksawery (1959). (Rec.) Bibliografia Warszawy. Druki zwarte. Red. nauk. J. Durko. Kwartalnik Historyczny R. 66, nr 4, s. -1295-1297.

Tyrowicz, Marian (1959). (Rec.) Bibliografia Warszawy. Druki zwarte. Red. nauk. J. Durko. Polska Wspótczesna i Dawna nr 1/2, s. 241-243.

Zaręba, Halina (1965). (Rec.) Bibliografia Warszawy. Wydawnictwa ciągłe. 1944-1954. Red. J. Durko. Przeglad Biblioteczny R. 33, z. 4, s. 245-247.

Zawadzki, Konrad (1965a). (Rec.) Bibliografia Warszawy. Wydawnictwa ciągłe. 1944-1954. Red. J. Durko. Rocznik Warszawski [R.] 6, s. 292-302.

Zawadzki, Konrad (1965b). (Repl.) Bibliografia Warszawy. Wydawnictwa ciągłe. 19441954. Red. J. Durko. Rocznik Warszawski (R.) 6, s. 309-311.

Znajomski, Artur (2015a). Początki bibliografii lokalnej w Polsce. Józef Ignacy Kraszewski i jego bibliografia druków wileńskich. Toruńskie Studia Bibliologiczne nr 2, s. 33-53.

Znajomski, Artur (2015b). Sprawność informacyjna bibliografii lokalnych wydanych w Polsce w latach 1945-1989. W: Dymmel A., Kotuła S. D., Znajomski A. Kultura czytelnicza i informacyjna - teoria i praktyka. Wybrane zagadnienia. Lublin: Wydaw. UMCS, s. $101-150$.

Żbikowska-Migoń, Anna (2008). Rola czasopism w krytyce piśmiennictwa naukowego. W: Dokument, ksiażka i biblioteka w badaniach naukowych i nauczaniu uniwersyteckim. Pod red. M. Skalskiej-Zlat i A. Żbikowskiej-Migoń. Wrocław: Wydaw. Uniwersytetu Wrocławskiego, s. 139-155.

Artykut w wersji poprawionej wpłyną do Redakcji 8 września 2018 r. 


\author{
ARTUR ZNAJOMSKI \\ Institute of Information and Library Studies \\ Maria Curie-Skłodowska University in Lublin \\ e-mail: aznajomski@o2.pl
}

\title{
LOCAL BIBLIOGRAPHIES IN THE OPINION OF CRITICS
}

KEYWORDS: Local bibliographies. Evaluation. Reviews.

ABSTRACT: Thesis/Objective - The aim of this article is to present issues discussed in the reviews of local bibliographies. Research methods - The author used the analysis and critique of reviews of Polish local bibliographies of general nature. Results and conclusions - The reviews discuss a number of important issues such as the selection of the documents, description, arrangement, retrieval and auxiliary tools and typographical order of the bibliographies. The research shows that the prevailing number of the analyzed bibliographies includes various shortcomings as regards method and editing. In order to avoid such mistakes the bibliographies should be evaluated more often by the professionals while being prepared for the publication. 